\title{
OS CAMINHOS DA EDUCAÇÃO MÉDICA
}

O conceito de educação médica se desenvolveu nos últimos séculos em paralelo à evolução da medicina, e acreditamos que uma reflexão sobre este processo seja extremamente profícua e elucidativa justamente nesta fase da educação médica brasileira, caracterizada pela desordenada proliferação de escolas médicas e de um profundo questionamento do paradigma curricular vigente na maior parte destas faculdades.

$\mathrm{Na}$ era medieval, nas primeiras escolas de medicina, o ensino médico consistia basicamente no estudo e recitação dos textos hipocráticos e galênicos não necessariamente associados ao ensino prático supervisionado da profissão. Com a evolução do estudo da anatomia, especialmente na escola de Pádua com Vasalius (I5|4-|564), e posteriormente com o desenvolvimento da anatomia patológica com Morgagni (I682-177I) e Virchow (1821-1902), da microbiologia com Koch (1843-1910) e Pasteur (1822-1895) e da fisiologia com Claude Bernard (1813-1878), o estudo da medicina se modificou para incorporar também estes conhecimentos oriundos destas áreas básicas para embasar a prática desta nascente medicina científica. Tais modificações no cenário médico e científico levaram, portanto, a uma radical mudança curricular, ao exigir uma sólida formação científica pré-médica e a introdução curricular das citadas cadeiras básicas, acompanhadas de laboratórios e de professores que simultaneamente se dedicavam ao ensino eà pesquisa. As cadeiras clínicas, agora prefaciadas por cerca de dois anos de dedicação integral às disciplinas básicas, introduziriam os alunos ao cuidado dos pacientes dentro de hospitais universitários, sob a liderança de experientes médicos de reconhecida habilidade clínica e didática. A formação clínica seria então inteiramente baseada na cuidadosa observação dos doentes e na abordagem dos problemas clínicos presentes nestes mesmos pacientes. Nas palavras do grande médico e educador William Osler (1849-1919): "No método de ensino que pode ser chamado de natural, o estudante começa com o paciente, continua com o paciente e termina seus estudos com o paciente, usando livros e aulas como ferramentas, como meios para um fim. $O$ estudante começa, de fato, como um médico, como um observador de máquinas quebradas cuja estrutura e funções usuais thes são perfeitamente familiares. Ensine-o como observar, dê a ele muitos fatos a serem observados e as lições virão destes mesmos fatos. Para o estudante que está no início, tanto na clínica médica como na cirurgia, é uma regra segura não ensinar sem ter um paciente como texto, pois o melhor ensinamento é aquele veiculado pelo próprio paciente. Toda a arte da medicina está na observação, como fala o velho ditado, mas para educar os olhos para ver, o ouvido para ouvir e o dedo para sentir demora. Iniciar um homem no caminho correto é tudo o que podemos fazer. Esperamos muito dos estudantes e tentamos ensiná-los demais. Dai a eles bons métodos e um ponto de vista adequado e todos os demais conhecimentos serão acrescidos conforme sua experiência se acumule" (Aequanimitas; "The Hospital as a College").

Este ideal de educação médica antecedida de formação científica pré-médica, cujo ensino básico estava a cargo de investigadores e ocorria em laboratórios especializados e cuja formação clínica acontecia em hospitais universitários por professores do mais alto gabarito clínico foi, primeiramente, atingido na Faculdade de Medicina da Universidade John Hopkins, em Baltimore, nos Estados Unidos. Esta escola, fundada em 1893, da qual Osler foi o primeiro professor de Clínica Médica, se tornou um modelo para todas as escolas americanas até hoje. De fato, o grande educador Abraham Flexner (1866-1959), que redigiu um famoso rela tório que leva seu nome em 1910 e que revolucionou a educação médica americana e européia desde então, descreveu a situação desesperadora de muitas das 155 faculdades de medicina dos Estados Unidos e Canadá daquela época: "As escolas médicas eram essencialmente iniciativas privadas cujo espírito e objetivo eram gerar dinheiro... Um homem que pagasse suas mensalidades estava, assim, praticamente assegurado de conseguir seu título (de médico) mesmo que assistisse ou não às aulas". O relatório Flexner disponível on-line (http:/ www. carnegiefoundation.org/elibrary/docs/ flexner_report.pdf) foi responsável pelo fechamento de várias destas escolas médicas que não tinham condições adequadas de ensino nos anos seguintes e levou ao financiamento de várias outras para se adequarem ao modelo da John Hopkins, o que resultou na promoção da educação médica ameri cana, por conseguinte, para uma posição de destaque até hoje no mundo.

A prática da medicina mudou nos últimos anos, o que, com certeza, vai se refletir também no universo educacional. De fato, a atenção médica se desenvolve de forma crescente no cenário ambulatorial, enquanto que na maioria das escolas o ensino ainda se baseia em pacientes internados. Trazer e educar alunos nos ambulatórios é um grande desafio e uma tarefa extremamente proveitosa, pois seguramente o consultório é o melhor local para que $\mathrm{o}$ aluno aprenda a relação médicopaciente sob a tutela do professor que assiste a seus próprios doentes.

A explosão da informação médica pode também confundir alunos e professores, e o ensino das técnicas informatizadas para a busca destas informações, bem como formação para analisá-las de forma a responder perguntas clínicas específicas, se impõe no ensino médico atual. A prática de uma medicina baseada em evidências é, pois, um paradigma a ser progressivamente inculcado em professores e alunos para lhes permitir trabaIhar de forma ordenada, crítica e reflexiva diante do enorme manancial de novas informações médicas que se acumulam mês a mês.

Uma das tendências que surgiram nos últimos anos é o ensino da medicina "baseado em problemas". Através deste paradigma educacional, alunos desde o início de seu curso médico são expostos a problemas clínicos, e estimulados, sob supervisão de tutores, a buscarem as informações pertinentes na literatura médica para resolvê-los. Não podemos esquecer, entretanto, que o mais estimulante dos "problemas" na medicina é o próprio 
doente e que o ensino focado no paciente, à beira de seu leito, após uma sólida formação básica, conforme Osler nos ensinou acima, talvez seja a mais edificante das experiências educacionais de nossa profissão. De fato, já dizia este grande educador: "Eu não desejo nenhum outro epitáfio ... a não ser que ensinei estudantes de medicina nas enfermarias, pois eu julgo esta de longe a principal e mais útil função que fui chamado a desempenhar." (Aequanimitas; "The fixed period").

Com o aumento da complexidade das relações entre fontes pagadoras e o geren- ciamento público e privado na área da saúde, o médico deve hoje ter também conhecimentos básicos que the permitam gerir sua própria estrutura de atendimento. Além destes desafios, o médico se defronta ainda com um importante papel social educativo, para o qual deve se preparar para lidar com a diversidade cultural da população a que ele assiste. Este preparo foge das disciplinas básicas e clínicas e se lança pelas huma nísticas, que foram esquecidas nos últimos anos. O médico deve, em verdade, também se tornar um humanista, porque como disse Pelegrino: "A Medicina é a mais humana das ciências, a mais empírica das artes e a mais científica das humanidades".

Desta forma, face às complexidades que surgiram desde os tempos de Osler e Flexner, nós, médicos brasileiros, nos defrontamos com novos desafios educacionais. Entretanto, vencer estes desafios talvez não seja tão difícil como emular o exemplo de Flexner e, ao avaliar criticamente as escolas médicas brasileiras, conhecer e investir naquelas que consigam, de fato, formar médicos da estatura que preconizava Osler. 